\title{
PENGEMBANGAN MEDIA PEMBELAJARAN BERBASIS COOPERATIVE LEARNING UNTUK MATA PELAJARAN ILMU PENGETAHUAN ALAM (IPA)
}

\author{
Novi Larasati', Julaga Situmorang ${ }^{2}$, Hamonangan Tambunan ${ }^{3}$ \\ ${ }^{1}$ Sekolah Dasar Negeri 101784 Mabar, Sumatera Utara \\ ${ }^{2,3}$ Pascasarjana Universitas Negeri Medan \\ Novilarasati87@gmail.com ${ }^{1}$
}

\begin{abstract}
Abstrak: Penelitian ini bertujuan untuk: (1) menghasilkan media pembelajaran interaktif yang layak digunakan, mudah dipelajari dan dapat dipakai untuk pembelajaran individual, (2) untuk mengetahui keefektifan media pembelajaran interaktif yang dikembangkan untuk pembelajaran IPA pada siswa sekolah dasar. Jenis penelitian ini adalah penelitian pengembangan yang menggunakan model pengembangan produk Borg dan Gall yang dipadu dengan model pengembangan pembelajaran Dick dan Carey. Model pengembangan produk pembelajaran ini merupakan model yang disusun secara terprogram dengan urutan yang sistematis dan memenuhi karakteristik siswa usia SD dalam belajar. Hasil penelitian menunjukkan: (1) uji ahli materi IPA berada pada kualifikasi sangat sesuai (95,08 \%), (2) uji ahli desain pembelajaran berada pada kualifikasi sangat sesuai (93,96\%), (3) uji ahli rekayasa perangkat lunak dan desain grafis berada pada kualifikasi sangat sesuai (86,70 \%), uji coba perorangan berada pada kualifikasi sangat sesuai (91,43 $\%)$, uji coba kelompok kecil berada pada kualifikasi sangat sesuai $(93,63 \%)$, uji coba lapangan berada pada kualifikasi sangat sesuai (97.96\%). Dengan demikian, pengujian hipotesis membuktikan bahwa terdapat perbedaan yang signifikan antara hasil belajar siswa yang dibelajarkan dengan menggunakan media pembelajaran interaktif dan hasil belajar siswa yang dibelajarkan dengan menggunakan media pembelajaran poster.
\end{abstract}

Kata Kunci: Pengembangan Media Pembelajaran, Cooperative Learning, Mata Pelajaran IPA

Abstract: This study aims to: (1) produce interactive learning media that are feasible to use, easy to learn and can be used for individual learning, (2) to determine the effectiveness of interactive learning media developed for science learning in elementary school students. This type of research is development research that uses the Borg and Gall product development model combined with the learning development model of Dick and Carey. This learning product development model is a model that is arranged in a programmed order in a systematic order and meets the characteristics of elementary school age students in learning. The results showed: (1) the IPA material expert test was very suitable (95.08\%), (2) the learning design expert test was very appropriate (93.96\%), (3) the software engineering expert test and graphic design are very suitable qualifications (86.70\%), individual trials are very suitable qualifications (91.43\%), small group trials are very suitable qualifications $(93.63 \%)$, field trials are the qualifications are very appropriate (97.96\%). Thus, hypothesis testing proves that there are significant differences between student learning outcomes that are learned using interactive learning media and student learning outcomes that are learned using poster learning media.

Keywords: Development of Learning Media, Cooperative Learning, Science Subjects

\section{PENDAHULUAN}

Tujuan mata pelajaran Ilmu Pengetahuan Alam dalam Kurikulum Tingkat Satuan Pendidikan (2006:13) agar siswa memiliki kemampuan sebagai berikut : a) memperoleh keyakinan terhadap kebesaran Tuha Yang Maha Esa berdasarkan keberadaan, keindahan dan keteraturan alam ciptaan-Nya, b) mengembangakan pengetahuan dan konsepkonsep IPA yang bermanfaat dan dapat diterapkan dalam kehidupan sehari-hari, c) mengembangkan rasa ingin tahu, sikap positif, dan kesadaran tentang adanya hubungan yang saling mempengaruhi antara IPA, lingkungan, teknologi dan masyarakat, d) mengembangkan keterampilan proses untuk menyelidiki alam sekitar, memecahkan masalah dan membuat keputusan, e) meningkatkan kesadaran untuk berperanserta dalam memelihara, menjaga dan melestarikan lingkungan alam.

Model pembelajaran IPA yang cocok untuk anak-anak sekolah dasar Indonesia adalah belajar melalui pengalaman langsung (learning doing). Model belajar ini memperkuat daya ingat anak dan biayanya sangat murah sebab menggunakan alat-alat dan media belajar yang ada dilingkungan anak sendiri.

Pembelajaran dan tujuan IPA khususnya di SD/Mi dalam Kurikulum 2006 (KTSP) ini tentunya mengacu pada hakikat 
belajar, ciri-ciri belajar, dan prinsip-prinsip belajar. Dimana peserta didik belajar bukan hanya mengtahui, melainkan mengalami sehingga dapat mengaplikasikannya dalam kehidupan sehari-hari. Fungsi dan peran guru hanya sebagai moderator, siswa leebih proaktif untuk merumuskan sendiri tentang fenomena yang berkaitan dengan fokus kajian secara kontektual bukan tekstual.

Menurut Mayer (2003), siswa dapat belajar lebih baik di lingkungan dimana alat pembelajaran multimedia yang dirancang dengan baik . Klaim ini didasarkan pada fakta bahwa siswa belajar lebih baik dengan gambar dan kata-kata (visual dan verbal) daripada dengan kata-kata sendiri. Selanjutnya, Schnotz (2008) menekankan bahwa ada efek multimedia yang berbeda pada sistem kognitif pelajar, seperti efek pengaktifan, dan efek fasilitasi. Efek yang memungkinkan mengurangi waktu belajar dan beban kognitif, sementara efek memudahkan memungkinkan peserta didik untuk memanipulasi gambar yang berbeda dari gambar statis; Namun, situasi ini terkadang menyebabkan pembelajaran yang tidak efektif (Schnotz \& Rasch, 2005).

Selain keunggulan ini, efek positif multimedia lainnya dalam pengajaran dan pembelajaran terkait dengan motivasi peserta didik. Elliot dkk. (2014) menyatakan bahwa alat multimedia meningkatkan motivasi peserta didik dalam proses pembelajaran sains. Selanjutnya, hasil studi review baru-baru ini yang dilakukan oleh Moos dan Marroquin (2010) menunjukkan bahwa berbagai jenis CAI, seperti multimedia, hypermedia dan hypertext, mempengaruhi konstruksi motivasi berbasis teori, seperti tujuan penguasaan, sasaran kinerja, minat individu, minat situasional, motivasi intrinsik, motivasi ekstrinsik dan selfefficacy.

Di sisi lain, menurut prinsip redundansi, menghadirkan peserta didik mendelegasikan narasi dan teks secara bersamaan tidak tepat (Pastore, 2012). Dengan demikian, materi pengajaran / pembelajaran multimedia dapat mempersulit atau menghambat proses belajar / mengajar, jika materi multimedia mengabaikan asas. Selain itu, prinsip segmentasi menunjukkan pentingnya kontrol pelajar terhadap materi multimedia (Mayer \& Moreno, 2003).

Model pembelajaran Cooperative Learning merupakan salah satu model pembelajaran yang mendukung pembelajaran kontekstual. Sistem pengajaran Cooperative Learning dapat didefinisikan sebagai sistem kerja/ belajar kelompok yang terstruktur. Menurut Johnson (1993) yang termasuk di dalam struktur ini adalah lima unsur pokok, yaitu saling ketergantungan positif, tanggung jawab individual, interaksi personal, keahlian bekerja sama, dan proses kelompok.

\section{Hakekat Media Pembelajaran}

Kata media berasal dari bahasa Latin dan merupakan bentuk jamak dari kata medium yang secara harfiah dapat diartikan sebagai perantara atau pengantar. Ramiszowski dalam Oemar (2003:201) mendefinisikan media pengajaran "...as the carries of messages, from some transmitting sources (which may be a human being or an intimate object, to the receiver of the message which in our case is the learner)," sedangkan AECT (Association of Education and Communication) dalam Arsyad (2003:3) memberi batasan tentang media sebagai segala bentuk dan saluran yang digunakan untuk menyampaikan pesan atau informasi.

Menurut Brigg dalam Arsyad (2003:4) media adalah segala alat fisik yang dapat menyajikan pesan yang merangsang yang sesuai untuk belajar, misalnya media cetak, media elektronik film dan video. Heinich (2011:8) menyatakan bahwa : "A medium (plural media) is a channel of communication, example include film, television, diagram, printed materials, computers, andinstructors. (Media adalah saluran komunikasi termasuk film, televisi, diagram, materi tercetak,komputer, dan instruktur).

Briggs menyatakan bahwa media pembelajaran sebagai "the physical means of conveying instructional content ... book, films, videotapes, etc". Lebih jauh Briggs menyatakan media adalah "alat untuk memberi perangsang bagi peserta didik supaya terjadi proses belajar." Menurut Wood (2001:15), penggunaan multimedia pembelajaran berpotensi meningkatkan pembelajaran kosakata. Dalam multimedia pembelajaran dapat disajikan bentuk permainan, hyperlink, hypertext, dan animasi.

Miarso (2009: 458) mengemukakan bahwa media pembelajaran adalah segala sesuatu yang dapat digunakan untuk menyalurkan pesan dari pengirim ke penerima pesan. Dalam hal ini adalah proses merangsang pikiran, perasaan, perhatian, dan minat serta 
perhatian siswa sehingga proses belajar dapat terjalin.

\section{Hakekat Media Pembelajaran Interaktif}

Klasifikasi media pembelajaran menurut Arsyad (2003:33) dibagi atas empat kelompok yaitu: (1) media hasil teknologi cetak; (2) media hasil teknologi audio-visual; (3) media hasil teknologi berbasis komputer; dan (4) media hasil gabungan teknologi cetak dan komputer. Seels dalam Arsyad (2003:35) beranggapan bahwa klasifikasi media pembelajaran terbagi atas :

a) Media tradisional yang merupakan : (1) visual diam yang diproyeksikan, contohnya proyeksi overhead, slides, filmstrips, (2) visual yang tak diproyeksikan yaitu gambar, poster, foto, charts, grafik, diagram, pameran, papan info, papan-bulu, (3) audio yaitu rekaman piringan, pita kaset, reel, cartridge, (4) penyajian multimedia contohnya slide plus suara (tape), (5) Visual dinamis yang diproyeksikan seperti film, televisi, video, (6) Media cetak yaitu buku teks, modul, teks terprogram, workbook, majalah ilmiah, lembaran lepas (hand-out), (7) Permainan yaitu teka-teki, simulasi, permainan papan, dan (8) Media realia yaitu model, specimen (contoh), manipulatif (peta, boneka).

b) Media teknologi mutakhir yang merupakan: (1) Media berbasis telekomunikasi seperti telekonferen, kuliah jarak jauh, (2) Media berbasis mikroprosesor yaitu computer-assisted instruction, permainan komputer, sistem tutor intelijen, interaktif, hipermedia, dan compact disc (video).

Menurut Arsyad (2003:36) media pembelajaran interaktif adalah suatu sistem penyampaian pengajaran yang menyajikan materi video rekaman dengan pengendalian komputer kepada penonton (siswa) yang tidak hanya mendengar dan melihat video dan suara, tetapi juga memberikan respon yang aktif, dan respon itu yang menentukan kecepatan dan sekuensi penyajian.

Perencanaan multimedia pembelajaran interaktif ini mengacu pada model pengembangan Borg \& Gall (2005).
Perencanaan multimedia pembelajaran interaktif ini berada dalam kawasan pengembangan. Menurut Seels \& Richey (1994) kawasan pengembangan berakar pada produksi media.

Teori belajar kognitif yang berakar pada teori pemrosesan informasi merupakan landasan dari pengembangan multimedia/hypermedia. (Sweller: 1988) mengemukakan bahwa Cognitive load theory (CLT) adalah penjabaran lebih detail dari teori belajar kognitif yang secara khusus menekankan pada keterbatasan kapasistas working memory, disamping dual channel input, dan active processing. CLT telah digunakan untuk mendeskripsikan bangun kognisi manusia dan menjadi acuan dalam desain pembelajaran. Teori ini memberikan kerangka umum bagi desainer pembelajaran dalam mengontrol kondisi belajar pada suatu lingkungan atau material pembelajaran. Secara khusus, teori ini memberikan basis acuan empiris yang membantu desainer pembelajaran untuk mengurangi beban kognitif selama belajar. Metode pembelajaran yang membebani secara berlebihan (overload) working memory menyebabkan belajar menjadi lebih sulit (Mayer: 2011).

Berdasarkan tiga asumsi di atas, Mayer (2011) menjelaskan bahwa agar pembelajaran penuh makna (meaningful learning) terjadi dalam lingkungan multimedia, maka orang yang belajar harus melibatkan diri ke dalam lima proses kognitif: (1) memilih kata-kata yang relevan untuk pemrosesan dalam memori kerja verbal, (2) memilih gambar-gambar yang relevan untuk pemrosesan dalam memori kerja visual, (3) menata kata-kata yang terpilih ke dalam model mental kerja, (4) menata gambargambar yang terpilih ke dalam model mental visual, dan (5) memadukan representasi verbal dan visual dengan pengetahuan yang ada sebelumnya.

Berdasarkan studi empiris menggunakan basis CLT, Mayer (2011) mengemukakan beberapa tujuh prinsip dasar multimedia yang dapat dijadikan resep untuk bagaimana mendesain mendesain presentasi multimedia. Prinsip-prinsip tersebut dirangkum dalam Tabel 1 berikut ini: 
Tabel 1. Tujuh Prinsip Desain Pesan Multimedia Berdasarkan Riset

\begin{tabular}{|l|l|l|}
\hline No & \multicolumn{1}{|c|}{ Prinsip } & \multicolumn{1}{c|}{ Deskripsi } \\
\hline 1. & $\begin{array}{l}\text { Prinsip } \\
\text { Multimedia }\end{array}$ & $\begin{array}{l}\text { Siswa (pebelajar) bisa belajar lebih baik dari kata-kata dan gambar-gambar } \\
\text { daripada dari kata-kata saja }\end{array}$ \\
\hline 2. & $\begin{array}{l}\text { Prinsip } \\
\text { Keterdekatan } \\
\text { Ruang }\end{array}$ & $\begin{array}{l}\text { Siswa (pebelajar) bisa belajar lebih baik saat kata-kata dan gambar-gambar } \\
\text { terkait disajikan saling berdekatan daripada saling berjauhan di layar }\end{array}$ \\
\hline 3. & $\begin{array}{l}\text { Prinsip } \\
\text { Keterdekatan } \\
\text { Waktu }\end{array}$ & $\begin{array}{l}\text { Siswa (pebelajar) bisa belajar lebih baik saat kata-kata dan gambar-gambar } \\
\text { terkait disajikan secara simultan (bersamaan) daripada suksesif (bergantian) }\end{array}$ \\
\hline 4. & $\begin{array}{l}\text { Prinsip } \\
\text { Koherensi }\end{array}$ & $\begin{array}{l}\text { Siswa (pebelajar) bisa belajar lebih baik saat kata-kata, gambar-gambar atau } \\
\text { suara-suara yang sifatnya ekstra/tambahan dibuang daripada ditambahkan }\end{array}$ \\
\hline 5. & $\begin{array}{l}\text { Prinsip } \\
\text { Modalitas }\end{array}$ & $\begin{array}{l}\text { Siswa (pebelajar) bisa belajar lebih baik dari animasi dan narasi daripada } \\
\text { animasi dan teks } \text { on-screen. }\end{array}$ \\
\hline 6. & $\begin{array}{l}\text { Prinsip } \\
\text { Redundansi }\end{array}$ & $\begin{array}{l}\text { Siswa (pebelajar) bisa belajar lebih baik dari animasi dan narasi daripada } \\
\text { animasi, narasi dan teks } \text { on-screen }\end{array}$ \\
\hline 7. & $\begin{array}{l}\text { Prinsip } \\
\text { Perbedaan } \\
\text { Individual }\end{array}$ & $\begin{array}{l}\text { Pengaruh desain lebih kuat terhadap siswa-siswa berpengetahuan rendah } \\
\text { daripada berpengetahuan tinggi, dan terhadap siswa-siswa berkemampuan } \\
\text { spatial tinggi daripada berspatial rendah }\end{array}$ \\
\hline
\end{tabular}

Navigasi adalah faktor yang krusial
dalam pembelajaran mandiri berbasis multimedia/hypermedia. Pebelajar pemula perlu dipandu dengan perangkat bantuan (navigasi) yang memadai. Pembelajaran yang minimal guidannya tidak bekerja pada pebelajar pemula, namun pebelajar mungkin gagal dalam memperoleh informasi yang relevan apabila diberikan terlalu banyak kontrol. Perhatian atau atensi juga adalah aspek penting dalam belajar. Pembelajaran dengan multimedia mempunyai keunggulan pada aspek atensi dan peningkatan emosi yang positif terhadap pembelajaran (Park, \& Lim, 2007).

\section{Pembelajaran Kooperatif}

Pembelajaran kooperatif dibangun atas dasar teori konstruktivis sosial dari vygotsky dan teori perkembangan Vygotsky (zone of proximal development/ZPD) yang menyatakan bahwa pengetahuan dibangun melalui proses interaksi sosial, yaitu interaksi siswa dengan anggota komunitasnya yang lebih berkompeten. Interaksi sosial akan dapat menciptakan terjadinya pemrosan informasi pada individu siswa, sehingga siswa mampu melakukan dan menumbuhkan keinginan belajar, serta dapat berpengaruh positif terhadap motivasi dan hasil belajarnya. Penghargaan kelompok serta jadwal yang ketat memiliki struktur sangat penting untuk pembelajaran tim (Slavin, 1978; whicker, et. al 1997). Pembelajaran kooperatif, salah satu model pembelajaran berpusat pada siswa, telah didokumentasikan di seluruh literatur, efektif dalam membantu siswa memperoleh keterampilan praktis belajar, kemampuan komunikasi yang efektif dan kemampuan dalam hal pengetahuan pemahaman, dan mempromosikan sikap positif siswa terhadap pembelajaran mereka sendiri (Johnson \& Johnson, 2008; Slavin, 2011). Pembelajaran kooperatif juga berpengaruh pada penghargaan diri, perbaikan sikap terhadap mata pelajaran, teman sebaya, sekolah, serta gurunya, dan lebih terdorong untuk belajar dan berpikir (Lie, 2002). Dalam pembelajaran kooperatif, siswa belajar pada kelompok-kelompok kecil untuk mencapai tujuan yang sama dengan menggunakan keterampilan sosial.

Menurut Nur dalam Gulo (2002:30), semua model pembelajaran ditandai dengan adanya struktur tugas, struktur tujuan dan struktur penghargaan. Struktur tugas, struktur tujuan dan struktur penghargaan pada model pembelajaran kooperatif berbeda dengan struktur tugas, struktur tujuan serta struktur penghargaan model pembelajaran yang lain.

Berdasarkan latar belakang, identifikasi masalah, dan pembatasan masalah, maka masalah penelitian ini dapat dirumuskan sebagai berikut. Apakah media pembelajaran berbasis cooperative learning efektif digunakan untuk pembelajaran IPA di kelas V?

\section{METODE}

Penelitian ini dilaksanakan di Sekolah

Dasar Negeri 101784 Mabar. Populasi penelitian ini adalah siswa SDN 101784 Mabar, Kelas V Tahun Pelajaran 2015-2016 yang 
berjumlah 60 siswa. Kelas V terdiri dari V-a yaitu 30 orang dan $\mathrm{V}$-b yaitu 30 orang. Uji perseorangan dan uji kelompok kecil dilakukan di kelas V-a sedangkan uji kelompok besar dilakukan di kelas V-b.

Sasaran penelitian adalah pengembangan media pembelajaran multimedia interaktif pada mata pelajaran IPA. Pemilihan subjek penelitian ini berdasarkan pada kurangnya media pembelajaran multimedia pada mata pelajaran IPA di kelas V SD Negeri 101784 Mabar. Media yang dikembangkan tersebut berisi materi dan evaluasi yang disesuaikan dengan kebutuhan siswa dan kompetensi yang harus dikuasai siswa. Sedangkan sebagai subyek uji coba dalam penelitian dan pengembangan ini adalah siswa IV SD Negeri 101784 Mabar

Metode pengembangan yang digunakan dalam mengembangkan media pembelajaran ini adalah model pengembangan Borg and Gall (2005) yang dipadu dengan model pengembangan pembelajaran Dick and Carey (2005) yang memiliki langkah tahapan pengembangan sebagai berikut:

1) Melakukan penelitian pendahuluan, yang meliputi: (a) identifikasi kebutuhan pembelajaran dan menentukan standar kompetensi mata pelajaran, (b) melakukan analisis pembelajaran, (c) mengidentifikasi karakteritikdan perilaku awal peserta didik, (d) menulis kompetensi dasar dan indikatornya, (e) menulis tes acuan patokan; menyusun strategi pembelajaran yang terdiri dari: penjelasan tentang tujuan instruksional, penjelasan relevansi isi pelajaran baru, penjelasan tentang materi pelajaran atau konsep, prinsip, dan prosedur yang akan dipelajari peserta didik, tes formatif dan umpan balik, dan tindak lanjut. (f) Mengembangkan bahan pembelajaran.

2) Pembuatan desain software, yang meliputi; (a) pembuatan naskah, (b) pembuatan storyboard, (c) Pembuatan Flow Chart View.

3) Pengumpulan bahan, yang meliputi; (a) Pembuatan dan pengumpulan gambar (image) dan animasi, (b) Perekaman dan pengumpulan audio

4) Mengembangkan dan membuat media pembelajaran

5) Review dan ujicoba produk.

6) Uji keefektifan produk
Dalam rangka keperluan pengujian hipotesis penelitian, maka dalam hal ini perlu dilakukan teknik pengumpulan data. Teknik pengumpulan data pada penelitian ini rnenggunakan teknik tes dan non tes. Teknik tes digunakan untuk mengumpulkan data hasil belajar IPA siswa, sedangkan teknik non tes digunakan untuk mengumpulkan data produk

Analisa data dilakukan pada langkah validasi dan uji coba dengan menghitung skor yang diperoleh untuk menilai kualitas produk berupa media software pembelajaran yang dikembangkan. Data yang terkumpul dalam penelitian ini berupa data kuantitatif yaitu skor dengan skala 1-5 (skor1 untuk sangat kurang baik, skor 2 untuk kurang baik, skor 3 untuk sedang, skor 4 untuk baik,dan skor 5 untuk sangat baik).

Untuk meyakinkan standar kelayakan dan keefektifan produk dilakukan pengujian keefektifan produk yang dikembangkan dan ujit. Analisis data pada penelitian ini menggunakan teknik analisis kuantitatif.

Untuk melihat keefektifan media pembelajaran yang dieksperimenkan digunakan rumus perhitungan efektifitas berikut (Sugiyono 2008:305) :

Efektifitas $=$

jumlah skor yang diperoleh

jumlah skorideal

Tabel 1. Kriteria Penilaian Efektifitas Media Pembelajaran

\begin{tabular}{|c|c|c|}
\hline Nilai & Kriteria & Presentasi \\
\hline A & Sangat baik & $\begin{array}{c}81 \% \leq \mathrm{X} \leq \\
100 \%\end{array}$ \\
\hline B & Baik & $61 \% \leq \mathrm{X} \leq 80 \%$ \\
\hline C & Sedang & $41 \% \leq \mathrm{X} \leq 60 \%$ \\
\hline D & Kurang baik & $21 \% \leq \mathrm{X} \leq 40 \%$ \\
\hline E & Sangat kurang baik & $0 \% \leq \mathrm{X} \leq 20 \%$ \\
\hline
\end{tabular}

Untuk menguji homogenitas data, digunakan uji kesamaan dua varians. Dilakukan uji dua pihak dengan taraf signifiikasi 0,05 hipotesis di atas diuji dengan statistika :

$$
F=\frac{\text { Varians terbesar }}{\text { Varians terkecil }}
$$

(Sugiyono,

2008:199)

Kriteria pengujian hipotesis :

Ho diterima jika $\mathrm{F} \leq \mathrm{F}$ (V1, V2) dan Ho ditolak jika $\mathrm{F} \geq \mathrm{F}(\mathrm{V} 1, \mathrm{~V} 2)$

Untuk melihat apakah ada perbedaan yang signifikan antara hasil belajar dengan penggunaan media pembelajaran interaktif dan konvensional (gambar) maka dilakukan uji 
hipotesis dengan uji $t$ menurut Sudjana (2005:239) sebagai berikut :

$$
\begin{aligned}
t_{\text {hitung }} & =\frac{\overline{x 1}-\overline{x 2}}{s_{\sqrt{\frac{1}{n 1}}+\frac{1}{n 2}}} \\
& \text { dengan } \mathrm{S}^{2}=\frac{(n 1-n 2) s 1^{2}+(n 2-n 1) s 12^{2}}{n 1+n 2-2} \\
& \text { dengan } \mathrm{db}=\mathrm{n}_{1}+\mathrm{n}_{2}-2
\end{aligned}
$$

Kriteria korelasi yang diperoleh dikatakan signifikan (hipotesis diterima) jika harga $\mathrm{t}_{\text {hitung }}>\mathrm{t}_{\text {tabel }}$ untuk taraf signifikasi 0,05 Keterangan :

$\mathrm{t}_{\text {hitung }}=$ harga $\mathrm{t}$ hasil perhitungan

$\overline{x 1}=$ rata - rata skor kelas eksperimen

$\overline{x 2}=$ rata - rata skor kelas kontrol

$\mathrm{n}_{1}=$ jumlah sampel kelas eksperimen

$\mathrm{n}_{2}=$ jumlah sampel kelas kontrol

$s 1^{2}=$ varians pada kelas eksperimen

$s 2^{2}=$ varians pada kelas kontrol
$\mathrm{SD}=$ standar deviasi gabungan

Adapun rumusan hipotesis statistik ini dinyatakan sebagai berikut:

Hipotesis : $\mathrm{H}_{\mathrm{o}}: \mu 1=\mu 2$

$$
\mathrm{H}_{\mathrm{a}}: \mu 1>\mu 2
$$

\section{Keterangan}

$\mu 1=$ rata -rata hasil belajar IPA siswa yang diajarkan dengan menggunakan media pembelajaran interaktif

$\mu 2=$ rata -rata hasil belajar IPA siswa yang diajarkan dengan menggunakan pembelajaran konvensioanl (gambar)

\section{HASIL DAN PEMBAHASAN}

Hasil uji coba berupa skor penilaian terhadap media pembelajaran interaktif pada mata pelajaran IPA pada uji coba perorangan

\begin{tabular}{|c|c|c|c|c|c|c|c|}
\hline \multirow{2}{*}{ No } & \multirow{2}{*}{ Indikator Penilaian } & \multicolumn{3}{|c|}{ Responden } & \multirow{2}{*}{$\begin{array}{l}\text { Jumlah } \\
\text { Skor }\end{array}$} & \multirow{2}{*}{ Rata-rata } & \multirow{2}{*}{ Kriteria } \\
\hline & & $\mathbf{1}$ & 2 & 3 & & & \\
\hline 1 & Kesesuaian materi & 5 & 5 & 5 & 15 & $100,00 \%$ & Sangat sesuai \\
\hline 2 & Kejelasan petunjuk belajar & 5 & 4 & 5 & 14 & $93,33 \%$ & Sangat sesuai \\
\hline 3 & $\begin{array}{l}\text { Kemudahan memahami } \\
\text { kalimat pada teks }\end{array}$ & 4 & 5 & 4 & 13 & $86,67 \%$ & Sangat sesuai \\
\hline 4 & $\begin{array}{l}\text { Kemudahan memahami } \\
\text { pembelajaran }\end{array}$ & 4 & 5 & 4 & 13 & $86,67 \%$ & Sangat sesuai \\
\hline 5 & Ketepatan urutan penyajian & 4 & 5 & 4 & 13 & $86,67 \%$ & Sangat sesuai \\
\hline 6 & Kecukupan latihan & 5 & 5 & 4 & 14 & $93,33 \%$ & Sangat sesuai \\
\hline 7 & Kejelasan umpan balik & 5 & 5 & 5 & 15 & $100,00 \%$ & Sangat sesuai \\
\hline \multirow[t]{2}{*}{8} & $\begin{array}{l}\text { Bantuan belajar dengan } \\
\text { program }\end{array}$ & 4 & 4 & 5 & 13 & $86,67 \%$ & Sangat sesuai \\
\hline & \multicolumn{4}{|l|}{ Rata-rata } & 91,67 & $93,33 \%$ & Sangat sesuai \\
\hline
\end{tabular}
dapat dilihat pada tabel berikut ini :

Tabel 2. Skor Penilaian Media Pembelajaran Interaktif IPA Berbasis Kooperatif Pada Uji Coba Perorangan tentang Kualitas Materi Pembelajaran

Tabel 2. menunjukkan tanggapan 3 siswa pada uji coba perorangan terhadap media pembelajaran interaktif mata pelajaran IPA dari aspek kualitas materi pembelajran dan secara keseluruhan dinyatakan dalam kriteria "Sangat
Sesuai". Penilaian siswa pada media pembelajaran interakitf tentang aspek kualitas teknik/tampilan dapat dilihat pada tabel berikut ini : 
Tabel 3. Skor Penilaian Media Pembelajaran Interaktif IPA Berbasis Kooperatif Pada Uji Coba Perorangan Tentang Aspek Kualitas Teknis/Tampilan

\begin{tabular}{|c|c|c|c|c|c|c|c|}
\hline \multirow{2}{*}{ No } & \multirow{2}{*}{ Indikator Penilaian } & \multicolumn{3}{|c|}{ Responden } & \multirow{2}{*}{$\begin{array}{l}\text { Jumlah } \\
\text { Skor }\end{array}$} & \multirow{2}{*}{$\begin{array}{l}\text { Rata- } \\
\text { rata }\end{array}$} & \multirow{2}{*}{ Kriteria } \\
\hline & & 1 & 2 & 3 & & & \\
\hline 1 & Keindahan Tampilan layar & 5 & 5 & 4 & 14 & 93,33 & Sangat sesuai \\
\hline 2 & Keterbacaan teks & 5 & 5 & 5 & 15 & 100,00 & Sangat sesuai \\
\hline 3 & Kualitas gambar dan animasi & 5 & 5 & 5 & 15 & 100,00 & Sangat sesuai \\
\hline 4 & Komposisi warna & 5 & 5 & 5 & 15 & 100,00 & Sangat sesuai \\
\hline 5 & Navigasi & 4 & 4 & 4 & 12 & 80,00 & Sesuai \\
\hline 6 & Daya dukung musik & 5 & 5 & 4 & 14 & 93,33 & Sangat sesuai \\
\hline \multirow[t]{2}{*}{7} & Interaksi & 5 & 5 & 5 & 15 & 100,00 & Sangat sesuai \\
\hline & \multicolumn{4}{|l|}{ Rata-rata } & 95,24 & $89,52 \%$ & Sangat sesuai \\
\hline
\end{tabular}

Hasil penilaian pada uji coba interaktif mata pelajaran Ilmu Pengetahuan perorangan terhadap aspek kualitas materi Alam dirangkum pada Tabel 4 berikut ini : pembelajaran terhadap media pembelajaran

Tabel 4. Tingkat Kecenderungan Penilaian Terhadap Aspek Kualitas Pembelajaran IPA Berbasis Berbasis Kooperatif Pada Uji Coba Perorangan

\begin{tabular}{|c|l|c|c|c|}
\hline No. & \multicolumn{1}{|c|}{ Kategorisasi } & Persentase & Frekuensi & Persentase \\
\hline 1 & Sangat sesuai & $81 \% \leq x \leq 100 \%$ & 3 & $100,00 \%$ \\
\hline 2 & Sesuai & $61 \% \leq x<80 \%$ & 0 & $0,00 \%$ \\
\hline 3 & Cukup sesuai & $41 \% \leq x<60 \%$ & 0 & $0,00 \%$ \\
\hline 4 & Kurang sesuai & $21 \% \leq x<40 \%$ & 0 & $0,00 \%$ \\
\hline 5 & Sangat kurang sesuai & $0 \% \leq x<20 \%$ & 0 & $0,00 \%$ \\
\hline & Jumlah & & $\mathbf{3}$ & $\mathbf{1 0 0 , 0 0 \%}$ \\
\hline
\end{tabular}

Untuk tingkat kecenderngan penilaian oleh siswa terhadap kualitas teknis atau tampilan $100 \%$ dinyatakan dalam kriteria
"Sangat Sesuai" yang dapat dilihat pada tabel berikut ini :

Tabel 5. Tingkat Kecenderungan Penilaian Terhadap Aspek Kualitas Teknis/Tampilan Media Pembelajaran Interaktif IPA Berbasis Kooperatif Pada Uji Coba Perorangan

\begin{tabular}{|c|c|c|c|c|}
\hline No. & Kategorisasi & Persentase & Frekuensi & Persentase \\
\hline 1 & Sangat sesuai & $81 \% \leq x \leq 100 \%$ & 3 & $100,00 \%$ \\
\hline 2 & Sesuai & $61 \% \leq x<80 \%$ & 0 & $0,00 \%$ \\
\hline 3 & Cukup sesuai & $41 \% \leq x<60 \%$ & 0 & $0,00 \%$ \\
\hline 4 & Kurang sesuai & $21 \% \leq x<40 \%$ & 0 & $0,00 \%$ \\
\hline \multirow[t]{2}{*}{5} & Sangat kurang sesuai & $0 \% \leq x<20 \%$ & 0 & $0,00 \%$ \\
\hline & Jumlah & & 3 & $100,00 \%$ \\
\hline
\end{tabular}

Berdasarkan hasil penilaian pada media pembelajaran interaktif IPA berbasis cooperatif learning pada uji coba perorangan tidak terdapat saran perbaikan. 
Tabel 6. Persentase Rata-Rata Hasil Penilaian Terhadap Media IPA Berbasis Kooperatif Pada Uji Coba Perorangan

\begin{tabular}{|c|l|c|c|}
\hline No. & \multicolumn{1}{|c|}{ Kategorisasi } & $\begin{array}{c}\text { Persentase rata- } \\
\text { rata }\end{array}$ & Kriteria \\
\hline 1 & Aspek kualitas materi pembelajaran & $93,33 \%$ & Sangat Sesuai \\
\hline 2 & Aspek kualitas teknis/tampilan & $89,52 \%$ & Sangat Sesuai \\
\hline & Rata-rata & $\mathbf{9 1 , 4 3 \%}$ & Sangat Sesuai \\
\hline
\end{tabular}

a. Data Hasil Uji Coba Tahap III Uji Coba Kelompok Kecil

Uji coba kelompok kecil ini digunakan sebagai pengalaman awal sebelum produk diujicobakan ke lapangan. Hasil evaluasi pada aspek kualitas materi pembelajaran dapat dilihat pada tabel berikut.

Tabel 7. Skor Penilaian Media Pembelajaran Interaktif IPA Berbasis Kooperatif Pada Uji Coba Kelompok Kecil

\begin{tabular}{|c|c|c|c|c|c|c|c|c|}
\hline \multirow{2}{*}{ No } & \multirow{2}{*}{ Indikator Penilaian } & \multicolumn{5}{|c|}{ Skor } & \multirow{2}{*}{$\begin{array}{l}\text { Rata- } \\
\text { rata }\end{array}$} & \multirow{2}{*}{ Kriteria } \\
\hline & & 1 & 2 & 3 & 4 & 5 & & \\
\hline 1 & Kesesuaian materi & & & & 6 & 6 & $90,00 \%$ & Sangat Sesuai \\
\hline 2 & Kejelasan petunjuk belajar & & & & 6 & 6 & $90.00 \%$ & Sangat Sesuai \\
\hline 3 & $\begin{array}{l}\text { Kemudahan memahami kalimat pada } \\
\text { teks }\end{array}$ & & & & 6 & 6 & $90,00 \%$ & Sangat Sesuai \\
\hline 4 & Kemudahan memahami pembelajaran & & & & 6 & 6 & $90,00 \%$ & Sangat Sesuai \\
\hline 5 & Ketepatan urutan penyajian & & & & 5 & 7 & $91.67 \%$ & Sangat Sesuai \\
\hline 6 & Kecukupan latihan & & & & 5 & 7 & $91,67 \%$ & Sangat Sesuai \\
\hline 7 & Kejelasan umpan balik & & & & 6 & 6 & $90.00 \%$ & Sangat Sesuai \\
\hline 8 & Bantuan belajar dengan program & & & & 4 & 8 & $93,33 \%$ & Sangat Sesuai \\
\hline \multicolumn{7}{|c|}{ Rata-rata } & $91,39 \%$ & Sangat Sesuai \\
\hline
\end{tabular}

Hasil penilaian uji coba kelompok kecil terhadap aspek kualitas teknis atau tampilan pada media pembelajaran multimedia interaktif pada mata pelajaran Ilmu Pengetahuan Alam dirangkum pada tabel berikut ini.

Tabel 8. Skor Penilaian Media Pembelajaran IPA Uji Coba Kelompok Kecil Pada Aspek Kualitas Teknis atau Tampilan

\begin{tabular}{|c|c|c|c|c|c|c|c|c|}
\hline \multirow{2}{*}{ No } & \multirow{2}{*}{ Indikator Penilaian } & \multicolumn{5}{|c|}{ Skor } & \multirow{2}{*}{ Rata-rata } & \multirow{2}{*}{ Kriteria } \\
\hline & & 1 & 2 & 3 & 4 & 5 & & \\
\hline 1 & $\begin{array}{l}\text { Keindahan tampilan } \\
\text { layar }\end{array}$ & & & & 4 & 8 & $93,33 \%$ & Sangat Sesuai \\
\hline 2 & Keterbacaan teks & & & & 6 & 6 & $90,00 \%$ & Sangat Sesuai \\
\hline 3 & $\begin{array}{l}\text { Kualitas gambar dan } \\
\text { animasi }\end{array}$ & & & & 4 & 8 & $93,33 \%$ & Sangat Sesuai \\
\hline 4 & Komposisi warna & & & & 1 & 11 & $98,33 \%$ & Sangat Sesuai \\
\hline 5 & Navigasi & & & & 1 & 11 & $98,33 \%$ & Sangat Sesuai \\
\hline 6 & Daya dukung musik & & & & 4 & 8 & $93,33 \%$ & Sangat Sesuai \\
\hline 7 & Interaksi & & & & 1 & 11 & $98,33 \%$ & Sangat Sesuai \\
\hline \multicolumn{7}{|c|}{ Rata-rata } & $\mathbf{9 5 , 8 7 \%}$ & Sangat Sesuai \\
\hline
\end{tabular}


Berdasarkan Tabel 8, hasil tanggapan siswa seluruhnya $(100 \%)$ menyatakan kriteria kelompok kecil terhadap aspek kualitas teknis dinilai "Sangat Sesuai". Hasil penilaian uji coba atau tampilan pada media pembelajaran IPA berbasis cooperative learning.

Tabel 9. Tingkat Kecenderungan Penilaian Terhadap Aspek Teknis atau Tampilan Media Pembelajaran IPA Berbasis Berbasis Kooperatif Pada Uji Coba Perorangan

\begin{tabular}{|c|l|c|c|c|}
\hline No. & \multicolumn{1}{|c|}{ Kategorisasi } & Persentase & Frekuensi & Persentase \\
\hline 1 & Sangat sesuai & $81 \% \leq x \leq 100 \%$ & 12 & $100,00 \%$ \\
\hline 2 & Sesuai & $61 \% \leq x<80 \%$ & 0 & $0,00 \%$ \\
\hline 3 & Cukup sesuai & $41 \% \leq x<60 \%$ & 0 & $0,00 \%$ \\
\hline 4 & Kurang sesuai & $21 \% \leq x<40 \%$ & 0 & $0,00 \%$ \\
\hline 5 & Sangat kurang sesuai & $0 \% \leq x<20 \%$ & 0 & $0,00 \%$ \\
\hline & Jumlah & & $\mathbf{1 2}$ & $\mathbf{1 0 0 , 0 0 \%}$ \\
\hline
\end{tabular}
Sesuai".

Berdasarkan Tabel 9, hasil tanggapan siswa seluruhnya (100\%) menyatakan "Sangat

Tabel 10. Tingkat Kecenderungan Penilaian Terhadap Aspek Kualitas Teknis atau Tampilan Media Pembelajaran Interaktif IPA Berbasis Kooperatif Pada Uji Coba Kelompok Kecil

\begin{tabular}{|c|l|c|c|c|}
\hline No & \multicolumn{1}{|c|}{ Kategorisasi } & \multicolumn{1}{|c|}{ Persentase } & Frekuensi & Persentase \\
\hline 1 & Sangat sesuai & $81 \% \leq x \leq 100 \%$ & 12 & $100,00 \%$ \\
\hline 2 & Sesuai & $61 \% \leq x<80 \%$ & 0 & $0,00 \%$ \\
\hline 3 & Cukup sesuai & $41 \% \leq x<60 \%$ & 0 & $0,00 \%$ \\
\hline 4 & Kurang sesuai & $21 \% \leq x<40 \%$ & 0 & $0,00 \%$ \\
\hline 5 & Sangat kurang sesuai & $0 \% \leq x<20 \%$ & 0 & $0,00 \%$ \\
\hline & Jumlah & & $\mathbf{1 2}$ & $\mathbf{1 0 0 , 0 0 \%}$ \\
\hline
\end{tabular}

Tabel 11. Persentase Rata-Rata Hasil Penilaian terhadap Media Pembelajaran Interaktif IPA Berbasis Kooperatif Pada Uji Coba Kelompok Kecil

\begin{tabular}{|c|l|c|c|}
\hline No. & \multicolumn{1}{|c|}{ Kategorisasi } & Persentase rata-rata & Kriteria \\
\hline 1 & Aspek kualitas materi pembelajaran & $91,39 \%$ & Sangat Sesuai \\
\hline 2 & Aspek kualitas teknis/tampilan & $95,87 \%$ & Sangat Sesuai \\
\hline & Rata-rata & $\mathbf{9 5 , 8 7 \%}$ & Sangat Sesuai \\
\hline
\end{tabular}

\section{d. Data Hasil Uji Coba Tahap IV Uji Coba Lapangan}

Hasil evaluasi terhadap media pembelajaran pada aspek kualitas materi pembelajaran dapat dilihat pada tabel berikut ini .

Tabel 12. Skor Penilaian Media Pembelajaran Interaktif IPA Berbasis Kooperatif Pada Aspek Kualitas Materi Pembelajaran

\begin{tabular}{|l|l|c|c|c|c|c|c|c|}
\hline \multirow{2}{*}{ No } & \multicolumn{1}{|c|}{ Indikator Penilaian } & \multicolumn{5}{c|}{ Skor } & Rata- & \multirow{2}{*}{ Kriteria } \\
\cline { 3 - 7 } & & $\mathbf{1}$ & $\mathbf{2}$ & $\mathbf{3}$ & $\mathbf{4}$ & $\mathbf{5}$ & rata & \\
\hline 1 & Kesesuaian materi & & & & 10 & 20 & $93,33 \%$ & Sangat Sesuai \\
\hline 2 & Kejelasan petunjuk belajar & & & & 9 & 21 & $94,00 \%$ & Sangat Sesuai \\
\hline
\end{tabular}




\begin{tabular}{|l|l|l|l|l|l|l|l|l|l|}
\cline { 5 - 7 } 3 & $\begin{array}{l}\text { Kemudahan memahami kalimat pada } \\
\text { teks }\end{array}$ & & & 19 & 11 & $87,33 \%$ & Sangat Sesuai \\
\hline 4 & Kemudahan memahami pembelajaran & & & & 14 & 16 & $90,67 \%$ & Sangat Sesuai \\
\hline 5 & Ketepatan urutan penyajian & & & & 17 & 13 & $88,67 \%$ & Sangat Sesuai \\
\hline 6 & Kecukupan latihan & & & & 15 & 15 & $90,00 \%$ & Sangat Sesuai \\
\hline 7 & Kejelasan umpan balik & & & & 9 & 21 & $94,00 \%$ & Sangat Sesuai \\
\hline 8 & Bantuan belajar dengan program & & & & 6 & 24 & $96,00 \%$ & Sangat Sesuai \\
\hline \multicolumn{3}{|c|}{ Rata-rata } \\
\hline
\end{tabular}

Hasil evaluasi terhadap media pembelajaran pada aspek kualitas teknis atau tampilan dapat dilihat pada tabel berikut.

Tabel 13. Skor Penilaian Media Pembelajaran Interaktif IPA Berbasis Kooperatif Pada Mata Pelajaran IPA Uji Coba Lapangan Pada Aspek Kualitas Teknis atau Tampilan

\begin{tabular}{|l|l|l|l|l|l|l|l|l|}
\hline \multirow{2}{*}{ No } & \multirow{2}{*}{ Indikator Penilaian } & \multicolumn{5}{|c|}{ Skor } & \multirow{2}{*}{ Rata-rata } & \multirow{2}{*}{ Kriteria } \\
\cline { 5 - 7 } & & $\mathbf{1}$ & $\mathbf{2}$ & $\mathbf{3}$ & $\mathbf{4}$ & $\mathbf{5}$ & & \\
\hline 1 & Keindahan tampilan layar & & & & 13 & 17 & $91,33 \%$ & Sangat Sesuai \\
\hline 2 & Keterbacaan teks & & & & 15 & 15 & $90,00 \%$ & Sangat Sesuai \\
\hline 3 & Kualitas gambar dan animasi & & & & 18 & 12 & $88,00 \%$ & Sangat Sesuai \\
\hline 4 & Komposisi warna & & & & 18 & 12 & $88,00 \%$ & Sangat Sesuai \\
\hline 5 & Navigasi & & & & 13 & 17 & $91,33 \%$ & Sangat Sesuai \\
\hline 6 & Daya dukung musik & & & & 13 & 17 & $91,33 \%$ & Sangat Sesuai \\
\hline 7 & Interaksi & & & & 12 & 18 & $92,00 \%$ & Sangat Sesuai \\
\hline \multicolumn{2}{|c}{ Rata-rata } & & & & $\mathbf{9 8 , 0 8 \%}$ & Sangat Sesuai \\
\hline
\end{tabular}

Hasil tanggapan siswa menyatakan (100\%) menyatakan "Sangat Sesuai". Hasil bahwa untuk aspek kualitas materi tanggapan siswa tersebut dapat dilihat pada pembelajaran pada uji coba lapangan di SDN tabel berikut.

101784 Mabar kelas V menunjukkan 60 orang

Tabel 14. Tingkat kecenderungan Penilaian Terhadap Aspek Kualitas Materi Pembelajaran IPA Berbasis Kooperatif Pada Uji Coba Lapangan

\begin{tabular}{|c|l|c|c|c|}
\hline No. & Kategorisasi & \multicolumn{1}{|c|}{ Persentase } & Frekuensi & Persentase \\
\hline 1 & Sangat sesuai & $81 \% \leq x \leq 100 \%$ & 60 & $100,00 \%$ \\
\hline 2 & Sesuai & $61 \% \leq x<80 \%$ & 0 & $0,00 \%$ \\
\hline 3 & Cukup sesuai & $41 \% \leq x<60 \%$ & 0 & $0,00 \%$ \\
\hline 4 & Kurang sesuai & $21 \% \leq x<40 \%$ & 0 & $0,00 \%$ \\
\hline 5 & $\begin{array}{l}\text { Sangat kurang } \\
\text { sesuai }\end{array}$ & $0 \% \leq x<20 \%$ & 0 & $0,00 \%$ \\
\hline & \multicolumn{1}{|l}{ Jumlah } & & $\mathbf{6 0}$ & $\mathbf{1 0 0 , 0 0 \%}$ \\
\hline
\end{tabular}

Hasil tanggapan siswa pada uji coba tampilan menunjukkan bahwa 60 orang (100\%) lapangan pada aspek kualitas teknis atau menyatakan "Sangat Sesuai". 
Tabel 15. Tingkat Kecenderungan Penilaian Terhadap Aspek Kualitas Teknis / Tampilan Media Pembelajaran IPA Berbasis Kooperatif

\begin{tabular}{|c|l|c|c|c|}
\hline No. & \multicolumn{1}{|c|}{ Kategorisasi } & \multicolumn{1}{|c|}{ Persentase } & Frekuensi & Persentase \\
\hline 1 & Sangat sesuai & $81 \% \leq x \leq 100 \%$ & 60 & $100,00 \%$ \\
\hline 2 & Sesuai & $61 \% \leq x<80 \%$ & 0 & $0,00 \%$ \\
\hline 3 & Cukup sesuai & $41 \% \leq x<60 \%$ & 0 & $0,00 \%$ \\
\hline 4 & Kurang sesuai & $21 \% \leq x<40 \%$ & 0 & $0,00 \%$ \\
\hline 5 & Sangat kurang sesuai & $0 \% \leq x<20 \%$ & 0 & $0,00 \%$ \\
\hline & Teknis atau Tampilan & $\begin{array}{c}\text { Teknis atau } \\
\text { Mampilan Media }\end{array}$ & $\begin{array}{c}\text { Teknis atau } \\
\text { Tampilan } \\
\text { Media }\end{array}$ & $\begin{array}{c}\text { Teknis atau } \\
\text { Tampilan Media }\end{array}$ \\
\hline
\end{tabular}

\section{Pada Uji Coba Lapangan di SDN 101784 Mabar Kelas V}

Pada uji coba lapangan dengan responden 60 siswa ternyata secara umum siswa menyatakan bahwa media pembelajaran yang dikembangkan Sangat Sesuai, dan tidak terdapat masalah yang harus diperbaiki. Dengan demikian tidak diadakan revisi IV pada tahap uji coba lapangan, yang juga berarti media pembelajaran interaktif telah siap untuk diuji keefektifannya.

Tabel 16 Persentase Rata-Rata Hasil Penilaian Terhadap Media Pembelajaran Interaktif IPA Berbasis Kooperatif Pada Uji Coba Lapangan

\begin{tabular}{|c|c|c|c|}
\hline No. & Kategorisasi & Persentase rata-rata & Kriteria \\
\hline 1 & Aspek kualitas materi pembelajaran & $97,84 \%$ & Sangat Sesuai \\
\hline 2 & Aspek kualitas teknis/tampilan & $98,08 \%$ & Sangat Sesuai \\
\hline & Rata-rata & $\mathbf{9 7 , 9 6 \%}$ & Sangat Sesuai \\
\hline
\end{tabular}

Berdasarkan analisis hasil penilaian pada uji coba perorangan yang dilakukan pada 3 siswa, tidak terdapat saran perbaikan produk pada media pembelajaran Bahasa Inggris berbasis multimedia interaktif. Revisi ketiga terhadap media pembelajaran interaktif IPA berbasis cooperatif learning dilakukan berdasarkan hasil uji coba kelompok kecil yang dilakukan pada 12 orang siswa. Adapun revisi yang dilakukan adalah penyesuaian bentuk huruf dan warna yang sesuai dengan materi. Berdasarkan analisis hasil penilaian pada uji coba lapangan yang dilakukan pada 60 orang siswa, tidak terdapat saran perbaikan produk pada media pembelajaran interaktif IPA berbasis cooperatif learning. Berdasarkan penilaian terhadap media pembelajaran interaktif IPA berbasis cooperatif learning pada uji coba lapangan dengan 60 siswa untuk aspek kualitas materi pembelajaran dan aspek kualitas teknis/tampilan menunjukkan bahwa produk yang dikembangkan Sangat Sesuai atau layak digunakan.

\section{a. Hipotesis 2}

Maka selanjutnya untuk pengujian hipotesis 2 dapat menggunakan Uji t hasil test.
Hal ini dilakukan untuk mengetahui apakah terdapat perbedaan kemampuan awal kelas kontrol dan kelas eksperimen dengan menggunakan uji t.

Menguji hipotesis dengan menggunakan uji-t

$$
\begin{gathered}
t_{\text {hitung }}=\frac{\overline{x^{1}}-\overline{x^{2}}}{s \sqrt{\frac{1}{n 1}}+\frac{1}{n 2}} \\
=\frac{22-\overline{21}}{17,08 \sqrt{\frac{1}{30}}+\frac{1}{30}} \\
=0,226
\end{gathered}
$$

dengan $\mathrm{S}^{2}=\frac{(n 1-n 2) s 1^{2}+(n 2-n 1) s 12^{2}}{n 1+n 2-2}=$ $\frac{(30-1) 14,57^{2}+(30-1) 19,28^{2}}{30+30-2}=17,08$

dengan $\mathrm{db}=\mathrm{n}_{1}+\mathrm{n}_{2}-2=30+30-2=58$

Berdasarkan hasil perhitungan yang diperoleh output $t_{\text {hitung }}$ sebesar 0,22 dan $t_{\text {tabel }}$ sebesar 1,67 pada taraf kepercayaan 95 persen. Maka diperoleh bahwa $t_{\text {hitung }}<t_{\text {tabel }}$ atau 0,22 < 1,67 atau dengan kata lain Ha ditolak. Hal ini menunjukkan bahwa kemampuan awal siswa kelas kontrol dan kelas eksperimen adalah cenderung sama dan tidak berbeda secara signifikan. Hipotesis penelitian ini adalah sebagai berikut: 
$\mathrm{Ha}$

$\begin{array}{lcr}: \quad \text { Media } & \text { pembelajaran yang } \\ \text { dikembangkan } & \text { mampu meningkatkan } \\ \text { hasil } & & \\ \quad \text { belajar IPA } & & \\ : \quad \text { Media } & \text { pembelajaran } & \text { yang } \\ \text { dikembangkan } & \text { tidak } & \text { mampu } \\ \text { meningkatkan } & & \\ \quad \text { hasil belajar IPA } & \end{array}$

Dengan kata lain H0 ditolak dan Ha diterima, maka dapatlah disimpulkan bahwa hasil belajar IPA siswa yang menggunakan media pembelajaran multimedia interaktif lebih tinggi dari siswa yang diajar dengan menggunakan buku teks dengan efektifitas penggunaan media interaktif sebesar $72,22 \%$. Keefektifan media pembelajaran interaktif diperoleh dengan cara sebagai berikut:

$X=\frac{\text { Jh skor yang diperoleh }}{\text { Jlh Skor maksimal }} \times 100 \%=\frac{650}{900} \times 100 \%=72,22 \%$

Nilai keefektifan media pembelajaran interaktif ini lebih tinggi dari nilai keefektifan pembelajaran tanpa media yaitu sebesar $71,33 \%$ yang diuraikan sebagai berikut:

$y=\frac{\text { Jlh skor yang diperoleh }}{\text { Jlh Skor maksimal }} \times 100 \%=\frac{642}{900} \times 100 \%=71,33 \%$

\section{Pembahasan}

Produk pengembangan media pembelajaran interaktif berbasis cooperative learning pada mata pelajaran IPA merupakan materi pembelajaran yang telah dikembangkan dengan memperhatikan aspek pembelajaran dan media sebagai prinsip desain pesan pembelajaran. Penelitian pengembangan produk yang dilakukan ini diarahkan untuk menghasilkan suatu produk berupa media pembelajaran IPA berbasis cooperative learning untuk siswa yang digunakan untuk meningkatkan proses pembelajaran maupun kompetensi siswa. Oleh sebab itu proses penelitian ini dilakukan dan diawali dengan (1) studi pendahuluan, (2) kemudian mendesain media pembelajaran, (3) melakukan validasi produk, dan (4) melakukan revisi dan penyempurnaan berdasarkan analisis data validasi dari ahli materi, ahli desain pembelajaran dan ahli rekayasa perangkat lunak yang dilanjutkan dengan uji coba perorangan, uji coba kelompok kecil, dan uji coba lapangan sehingga dihasilkan media pembelajaran yang layak digunakan sesuai dengan karakteristik bidang studi dan siswa sebagai pengguna.

\section{Pembahasan Hasil Penelitian Uji Keefektifan Produk}

Dari hasil pengolahan data penelitian yang dilakukan, terdapat perbedaan hasil belajar IPA antara siswa yang dibelajarkan dengan menggunakan media pembelajaran interaktif dan siswa yang dibelajarkan dengan tanpa media pembelajaran interaktif yaitu rata-rata hasil belajar IPA siswa yang dibelajarkan dengan menggunakan media pembelajaran interaktif lebih tinggi dibandingkan dengan siswa yang dibelajarkan tanpa menggunakan media pembelajaran interaktif. Maka, media yang telah dihasilkan adalah layak dan efektif untuk digunakan dalam pembelajaran. Hal ini sesuai dengan pendapat pakar dan hasil penelitian yang relevan sebagai berikut:

1) Keunggulan penggunaan multimedia interaktif dalam pembelajaran adalah seperti yang diungkapkan oleh Wood (2001: 15), penggunaan multimedia pembelajaran berpotensi meningkatkan hasil pembelajaran.

2) Teori pengajaran dari ahli psikologi Jerome Bruner (1995) yang menyatakan bahwa pengajaran seharusnya dimulai dari pengalaman langsung menuju representasi ikonik dan baru kemudian menuju representasi simbolik.

3) Hasil penelitian yang relevan. Penelitian yang dilakukan oleh Katz, D (2002: 72-76) membuktikan bahwa penggunaan multimedia dalam pembelajaran bahasa asing sangat membantu siswa, membuat mereka merasa senang dan menjadikan mereka lebih aktif dan mengurangi waktu guru untuk banyak menjelaskan.

\section{PENUTUP}

Berdasarkan rumusan, tujuan, hasil dan pembahasan penelitian pengembangan media pembelajaran interaktif berbasis cooperatif learning yang dikemukakan sebelumnya, maka dapat disimpulkan sebagai berikut:

a) Hasil validasi dari ahli materi terhadap media pembelajaran multimedia interaktif mata pelajaran IPA yang dikembangkan dengan menggunakan Macromedia Flash 8.0 secara keseluruan termasuk dalam kategori "Sangat Sesuai".

b) Hasil validasi dari ahli desain pembelajaran terhadap media pembelajaran multimedia interaktif mata pelajaran IPA yang dikembangkan termasuk dalam kriteria 
"Sangat Sesuai" sehingga dapat diterima dan layak digunakan dalam proses pembelajaran.

c) Hasil dari validasi dari ahli perangkat lunak terhadap dinilai sangat sesuai. Dengan demikian media pembelajaran multimedia interaktif yang dikembangkan secara keseluruhan termasuk dalam kriteria "Sangat Sesuai".

d) Menurut tanggapan siswa pada uji perorangan (uji satu-satu) siswa pada uji coba perorangan dinyatakan bahwa media pembelajaran multimedia interaktif yang dikembangkan dengan Macromedia Flash 8.0, dimana aspek materi pembelajaran, dan kualitas teknis/tampilan termasuk kategori "Sangat Sesuai".

e) Menurut tanggapan siswa pada uji coba kelompok kecil dinyatakan bahwa media pembelajaran multimedia interaktif yang dikembangkan dengan program Macrmedia Flash 8.0, dimana aspek materi pembelajaran, dan kualitas teknis/tampilan termasuk kategori "Sangat Baik".

f) Menurut tanggapan siswa pada uji coba lapangan dinyatakan bahwa media pembelajaran multimedia interaktif yang dikembangkan dengan Macromedia Flash, dimana aspek materi pembelajaran, dan kualitas teknis/tampilan termasuk kategori "Sangat Sesuai". Media pembelajaran yang dikembangkan peneliti layak untuk digunakan sebagai media pembelajaran IPA untuk siswa siswa SD Negeri 101784 Mabar

g) Berdasarkan tahapan validasi ahli materi, ahli desain, ahli perangkat lunak dan uji perorangan, uji kelompok kecil, serta uji lapangan dapat disimpulkan bahwa media pembelajaran multimedia interaktif menggunaakan Macromedia Flash 8.0 dinyatakan sesuai secara produk serta layak digunakan pada siswa tingkat Sekolah Dasar di SDN 101784 Mabar kelas V.

h) Efektifitas media pembelajaran interaktif yang dikembangkan lebih efektif untuk pembelajaran IPA kelas V.

\section{DAFTAR PUSTAKA}

Ahmad R. (1997) Media Instruksional Edukatif. Jakarta: Rineka Cipta

Anita Lie. (2007). Cooperative Learning. Jakarta : Grasindo
Arikunto, Suharsimi. (2003). Evaluasi Pembelajaran. Jakarta : Rineka Cipta

Arsyad, Azhar. (2003). Media pembelajaran. Jakarta: CV. Rajawali Djamarah

Borg, W R \& Gall, M D. (2005). Educational research: an introduction, Fourth Edition. New York: Longman. Inc.

Bruner, J.S. (1960). The Process of Education. London: Harvard University Press.

Bruner, J.S. (1961). "The Act of Discovery". Romey, W.D. (1968). Inquiry Techniques For Teaching Science. New Jersey : Prentice Hall, INC.,Englewood Cliffts.

Dick, W. Carey dan Carey, L. (2005). The systematic design of instruction. United States of America: Scott Foresman and Company.

Elliot D, Wilson D \& Boyle S. (2014). Science learning via multimedia portal resources: The Scottish case. British Journal of Educational Technology, 45(4):571-580. doi: $10.1111 /$ bjet.12085

Gulo, W.(2002). Strategi Belajar Mengajar. Jakarta: Grasindo

Heinich, R., \& Heinich, R. (2011). Instructional media and technologies for Learning. Englewood Cliffs, N.J: Merrill.

Johnson, E. B. (2002). Contextual Teaching and Learning. California : Corwin Press, INC.

Lie, A. (2002). Cooperative Learning. Jakarta: Geasindo.

Mayer RE \& Moreno R (2003). Nine ways to reduce cognitive load in multimedia learning. Educational Psychologist, 38(1):43-52. doi: 10.1207/S15326985EP3801_6

Mayer, Richard E. (2001). Multimedia Learning. terj: Teguh W. Utomo. Yogyakarta: Pustaka Pelajar.

Miarso, Yusufhadi. (2009). Menyemai Benih Teknologi Pendidikan. Jakarta: Prenada Media.

Moos DC \& Marroquin E (2010). Multimedia, hypermedia, and hypertext: Motivation considered and reconsidered. Computers in Human Behavior, 26(3):265-276. doi: 10.1016/j.chb.2009.11.004

Oemar H. (2003). Perencanaan Pengajaran Berdasarkan Pendekaatn Sistem. Jakarta: Bumi Aksara.

Park, S., \& Lim. J. (2007). Promoting Positive Emotion in Multimedia Learning Using Visual illustrations. Journal of 
Educational Multimedia and Hypermedia. 16(2). 141-163.

Pastore R. (2012). The effects of timecompressed instruction and redundancy on learning and learners' perceptions of cognitive load. Computers \& Education, 58(1):641-651.

doi:

10.1016/j.compedu.2011.09.018

Schnotz W \& Rasch T. (2005). Enabling, facilitating, and inhibiting effects of animations in multimedia learning: Why reduction of cognitive load can have negative results on learning. Educational Technology Research and Development, 53(3):47-58. doi: 10.1007/BF02504797

Schnotz W (2008). Why multimedia learning is not always helpful? In JF Roquet, R Lowe \& W Schnotz (eds). Understanding multimedia documents. New York: Springer. doi: 10.1007/978-0-387-733371

Slavin, Robert E. (2005). Cooperative Learning (cara efektif dan menyenangkan pacu prestasi seluruh peserta didik). Bandung: Nusa Media

Sudjana, (1992). Metode Statistika. Bandung : Tarsito.

Sudjana, Nana. (2009). Penilaian hasil proses belajar mengajar. Bandung: Rosda karya.

Sugiyono, (2008), Metode Penelitian Kuantitatif Kualitatif dan $R \& D$, Bandung: Alfabeta

Sweller, J. (1994). Cognitive load theory, learning difficulty and instructional design. Learning and Instruction, 4, 295 -312 .

Sweller, J. (1998). Cognitive architecture and instructional design. Educational Psychology Review, 10(3), 252 - 264.

Wood, J. (2001). Can software support children's vocabulary development? [versielektronik]. Journal of Language Learning \& Technology, 5, 166-265. 